\title{
Autoantibodies to cartilage and type II collagen in relapsing polychondritis and other rheumatic diseases
}

\author{
R. EBRINGER, ${ }^{1}$ G. ROOK, ${ }^{2} G$. T. SWANA, ${ }^{3}$ G. F. BOTTAZZO, \\ AND D. DONIACH ${ }^{4}$
}

From the ${ }^{1}$ Department of Rheumatology, the Middlesex Hospital, the ${ }^{2}$ Department of Microbiology, the Middlesex Hospital, Medical School, the ${ }^{3}$ Department of Immunology, St Thomas's Hospital, and the ${ }^{4}$ Department of Immunology, the Middlesex Hospital, Medical School

SUMmARY Cartilage antibodies were demonstrated by indirect immunofluorescence (IFL) on human fetal cartilage in 6 out of 9 patients with relapsing polychondritis (RPC), in 4 out of 260 patients with rheumatoid arthritis (RA), and in only 1 out of 1016 patients with other disorders. The antibodies were specific for cartilage and evenly stained the whole cartilage matrix. They were predominantly of IgG class and varied in titres from $1: 1$ to $1: 320$. Follow-up studies in the RPC patients indicated that higher titres were present during the early acute phase of the disease. Five of the 6 positive cases had developed the disease within the past 12 months, and the 3 negative cases had had the disease for 3 to 7 years when tested. The RA cases showing positive cartilage IFL had no clinical evidence of RPC. Sequential measurements in 2 of the 4 cases showed that these antibodies became detectable some years after the onset of arthritis. Absorption studies with human type II collagen and purified porcine proteoglycan failed to remove the cartilage IFL. Antibodies to human native type II collagen were measured by an enzyme-linked immunosorbent assay. The highest levels were found in the RA sera which also displayed cartilage IFL, but the 2 tests gave discordant results. RPC sera showed the same antibody levels by this method, as did cartilage-IFLnegative RA sera, though both groups had higher mean levels than healthy controls. The finding that cartilage antibodies are detected in the majority of cases of RPC and only rarely in other diseases suggests these antibodies may play an important role in the pathogenesis of cartilage destruction in RPC.

Relapsing polychondritis (RPC) is a rare but striking disease characterised by repeated attacks of cartilage inflammation and destruction. The main clinical features include auricular and nasal chondritis, nonerosive seronegative arthritis, tracheobronchial involvement, ocular inflammation, audiovestibular disease, and systemic vasculitis. ${ }^{12}$ There is some evidence that this disease has an autoimmune basis. About $30 \%$ of RPC patients have evidence of associated diseases such as rheumatoid arthritis (RA), polyarteritis, systemic lupus erythematosus (SLE), scleroderma, thyroid disease, Sjögren's disease, diabetes, or glomerulonephritis-diseases which are considered to have a major autoimmune component. Immunofluorescent cartilage antibodies were first detected by Dolan et al. ${ }^{3}$ and this has since

Accepted for publication 6 November 1980

Correspondence to $\mathrm{Dr} \mathrm{R}$. Ebringer, Middlesex Hospital, Arthur Stanley House, Tottenham Street, London W1P 9PG been confirmed by others. ${ }^{145}$ Most workers agree that the reactions are mainly against the cartilage matrix, though some have reported perilacunar or chondrocyte staining. ${ }^{6}$ Cellular immune reactions have also been described against cartilage extracts by means of lymphocyte transformation or macrophage migration inhibition methods. ${ }^{7-9}$

Recently antibodies to cartilage and type II collagen were described in the serum of 5 out of 15 patients with RPC. ${ }^{5}$ It was concluded that the antibodies detected by immunofluorescence (IFL) were identical with those reacting with collagen type II by means of a haemagglutination assay. Antibodies to various types of collagen have also been reported in patients with RA. ${ }^{10-13}$ We report here our observations on antibodies to human fetal cartilage using an indirect IFL assay and human type II collagen by means of an enzyme-linked immunoabsorbant assay (ELISA) in sera of patients with RPC, RA, and 
associated rheumatic, collagen, and autoimmune disorders.

\section{Materials and methods}

\section{PATIENTS STUDIED}

$R P C$ cases. The sera were obtained from various physicians and were collected over a period of 7 years.

$R A$ cases. The patients in this series were drawn from an ongoing prospective study of RA at the Middlesex Hospital. ${ }^{14}$ Stored sera were available over a period of up to 10 years. This made it possible to test previous samples from patients who were found to give a positive reaction to cartilage IFL.

Other groups. These were included as controls for the RPC cases. The sera were tested fresh or after storage at $-20^{\circ} \mathrm{C}$.

IMMUNOFLUORESCENCE ON CARTILAGE

Cartilage was obtained from the nasal septum and trachea of 4 human fetuses of 17 and 20 weeks gestation. Tests were also made on adult human cartilage, before and after hyaluronidase digestion, and on rat and guinea-pig tracheal cartilage for comparison with the human substrate. All sera were tested undiluted, and positive reactions were titrated in doubling dilutions to obtain an end-point titre. The standard indirect IFL test was done with fluorescein-labelled sheep antihuman Fab enriched immunoglobulin. Positive sera were also tested with specific conjugates for IgG, IgA, and IgM antibodies. Complement fixing antibodies were looked for with fluorescein conjugated anti-C3. Thyroid antibodies were titrated by the Wellcome Thymune $T$ and $M$ haemagglutination kits. Other tissue antibodies were detected by IFL on human stomach and pancreas and rat liver and kidney.

\section{ANTIGENS USED IN ELISA TEST}

Two preparations of collagen type II were used to coat the wells of the microtitre trays for the enzymelinked immunosorbent assay. Human collagen type II extracted from the intervertebral disc of a 14year-old boy was provided by Dr Helen Beard (Charles Salt Research Centre, Oswestry, Shropshire) as a solution in dilute acetic acid. The extraction procedure has been described. ${ }^{15}$ The second preparation, which gave identical results, was extracted from human articular cartilage ${ }^{16}$ and was provided by Dr V. Duance (Department of Animal Husbandry, University of Bristol) as a freeze-dried solid.

ENZYME-LINKED IMMUNOSORBENT ASSAY

This assay was performed in 96 well Micro-elisa trays (Dynatech). ${ }^{17}$ Collagen type II, dissolved in dilute acetic acid at a concentration of $1 \mathrm{~g} / \mathrm{l}$, was diluted to $10 \mathrm{mg} / \mathrm{l}$ in carbonate/bicabonate buffer

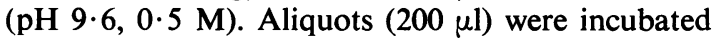
in the wells at $4^{\circ} \mathrm{C}$ for 3 hours. The wells were then washed 3 times in phosphate buffered saline (PBS), pH $7 \cdot 4$, containing $0.05 \%$ Tween 20 (PBS/Tween). Sera diluted $1 / 1000$ in PBS/Tween were then incubated in the wells for 2 hours at room temperature. After further washes in PBS/Tween a rabbit antiserum to IgG heavy chains (DAKO) conjugated with horseradish peroxidase (Sigma) was added to the wells and diluted 1/2000 in PBS/Tween. ${ }^{18}$ After overnight incubation and further washes the enzyme activity in the wells was assayed with O-phenylene diamine as substrate. The reactions were read in a spectrophotometer at $492 \mathrm{nM}$.

\section{Results}

\section{CARTILAGE IFL PATTERN}

There was a tissue-specific staining of the cartilage matrix which was even and diffuse but also brightest at the outer edge of the tissue. Chondrocytes were sometimes stained, but this was also seen with normal sera and has not been studied further. Fetal cartilage gave positive results without the need to prepare the substrate with hyaluronidase. When using adult human or animal cartilage treatment with $2 \%$ hyaluronidase at $37^{\circ} \mathrm{C}$ for 2 minutes was found to be essential to produce a positive result, as noted by previous investigators. ${ }^{15}$ The same IFL pattern was obtained with all positive sera including the RA cases. The guinea-pig and rat cartilage gave positive results only with the strongest fetal cartilage-positive sera, suggesting a weak species cross-reactivity.

\section{IFL ABSORPTION EXPERIMENTS WITH}

\section{HUMAN COLLAGEN TYPE II AND PURIFIED}

PORCINE PROTEOGLYCAN

Polymethylmethacrylate beads coated with $50 \mathrm{mg} / \mathrm{l}$ of the collagen type II preparation used in the ELISA tests and control beads coated with $200 \mathrm{mg} / \mathrm{l}$ of human serum albumin were incubated with various dilutions of cartilage-positive RPC sera for 1 hour at $37^{\circ} \mathrm{C}$ and overnight at $4^{\circ} \mathrm{C}$. The mixture was spun down and the supernatant then tested by IFL. Sera containing thyroid microsomal antibodies were treated in the same way as an added control. The absorption studies in repeated experiments failed to absorb the antibodies reactive by IFL. Purified porcine proteoglycan (obtained from $\mathrm{Dr}$ Helen Muir, Kennedy Institute of Rheumatology) made up to a final concentration of $5.6 \mathrm{~g} / 1$ was added to $1 / 10$ and $1 / 80$ dilutions of IFL cartilagepositive sera and incubated for 1 hour at $37^{\circ} \mathrm{C}$ and 
overnight at $4^{\circ} \mathrm{C}$. The mixture was then centrifuged at $21000 \mathrm{~g}$ for 30 minutes and the supernatants tested in parallel with positive control sera treated in the same way but omitting the proteoglycan. The porcine proteoglycan failed to remove the cartilage antibodies reactive by IFL.

\section{CLINICAL CORRELATIONS}

All the IFL results are detailed in Table 1.

$R P C$ patients. Six out of 9 patients with RPC gave the specific matrix IFL on fetal cartilage in titres of
$1: 1$ to $1: 160$. The antibodies were nearly all of $\mathrm{IgG}$ class and some fixed complement when tested with anti-C3 conjugates. Only 1 case had a weakly positive IgM IFL, and none were positive for IgA. Five of the 6 positive cases had developed the disease 4 to 12 months prior to testing, and 1 patient had a weakly positive result though tested 8 years after onset. Follow-up specimens were available in 5 of these cartilage-positive cases and only one became negative. Most of the patients showed high titres during the acute phase of the disease and in 2 of 3

Table 1 Clinical summary and follow-up studies in patients found to be positive for fetal cartilage antibody by immunofluorescence IFL. Other autoantibodies present in the sera are shown by the abbreviations below the Table

\begin{tabular}{|c|c|c|c|c|c|c|c|c|c|}
\hline \multirow{2}{*}{$\begin{array}{l}\text { Case } \\
\text { no. }\end{array}$} & \multirow{2}{*}{$\begin{array}{l}\text { Sexl } \\
\text { age }\end{array}$} & \multicolumn{2}{|c|}{ Diagnosis } & \multirow[t]{2}{*}{ Duration } & \multirow[t]{2}{*}{ Activity } & \multicolumn{2}{|c|}{ Cartilage antibodies } & \multirow[t]{2}{*}{ Other antibodies } & \\
\hline & & & & & & $\operatorname{Ig} G$ & $I g M$ & & \\
\hline \multirow[t]{3}{*}{1} & \multirow[t]{3}{*}{$M / 61$} & \multirow[t]{3}{*}{ RPC } & \multirow{3}{*}{$\begin{array}{l}\text { Auricular } \\
\text { histology + ve }\end{array}$} & $8 / 121974$ & $\mathbf{A}$ & $1: 80$ & - & & 一 \\
\hline & & & & Follow-up 1978 & I & $1: 1$ & - & & - (mucus) \\
\hline & & & & $\begin{array}{l}\text { Follow-up } 1978 \\
\text { Follow-up } 1979\end{array}$ & I & & & & \\
\hline \multirow[t]{3}{*}{2} & \multirow{3}{*}{$\mathrm{M} / 46$} & \multirow{3}{*}{ RPC } & \multirow{3}{*}{$\begin{array}{l}\text { Tracheobronchial } \\
\text { histology + ve } \\
\text { IgM cold agglutinin disease (anti-i) }\end{array}$} & $8 / 121977$ & A & $\begin{array}{l}1: 1 \\
1: 80\end{array}$ & $\overline{1: 5}$ & TGHA 1:320 & MCHA 1:102 \\
\hline & & & & & & & & & \\
\hline & & & & Follow-up 1978 & A & $1: 80$ & - & TGHA 1:5000 & MCHA $1: 10^{2}$ \\
\hline \multirow[t]{3}{*}{3} & \multirow{3}{*}{$\mathrm{M} / 54$} & \multirow{3}{*}{ RPC } & \multirow{3}{*}{$\begin{array}{l}\text { Tracheobroncial } \\
\text { histology + ve }\end{array}$} & $\begin{array}{l}\text { Follow-up } 1979 \\
12 / 121977\end{array}$ & $\begin{array}{l}\mathbf{A} \\
\mathbf{A}\end{array}$ & $\begin{array}{l}1: 80 \\
1: 80\end{array}$ & $1: 1$ & $\begin{array}{l}\text { TGHA 1:5000 } \\
\text { PCA }\end{array}$ & \\
\hline & & & & Follow-up 1977 & A & $1: 160$ & - & & \\
\hline & & & & Follow-up 1978 & $?$ & $1: 1$ & - & PCA & \\
\hline \multirow[t]{2}{*}{4} & \multirow{2}{*}{$\mathrm{M} / 52$} & \multirow[t]{2}{*}{ RPC } & \multirow{2}{*}{$\begin{array}{l}\text { Auricular } \\
\text { Ocular }\end{array}$} & $6 / 121978$ & A & $1: 5$ & - & & -- \\
\hline & & & & Follow-up 1978 & $?$ & - & - & & - \\
\hline \multirow[t]{3}{*}{5} & \multirow[t]{3}{*}{$F / 46$} & \multirow[t]{3}{*}{ RPC } & Arthritis & 8 yr 1976 & $\dot{A}$ & $1: 1$ & - & TGHA $1: 320$ & PCA 1:80 IF + \\
\hline & & & $\begin{array}{l}\text { Nasal } \\
\text { Audiovestibular }\end{array}$ & Follow-up 1979 & $\mathbf{A}$ & $1: 1$ & - & TGHA $1: 640$ & $\begin{array}{l}\text { PCA IF }+ \\
\text { ICA }++\end{array}$ \\
\hline & & & $\begin{array}{l}\text { histology +ve } \\
\text { Diabetes mellitus, thyrotoxicosis, } \\
\text { vitiligo }\end{array}$ & & & & & & \\
\hline \multirow[t]{2}{*}{6} & $F / 48$ & RPC & $\begin{array}{l}\text { Auricular } \\
\text { Ocular }\end{array}$ & $4 / 121978$ & $\mathbf{A}$ & $1: 1$ & - & & - \\
\hline & & & $\begin{array}{l}\text { Nasal } \\
\text { Tracheo-bronchial }\end{array}$ & & & & & & \\
\hline 7 & $M / 15$ & RPC & $\begin{array}{l}\text { Arthritis } \\
\text { Ocular }\end{array}$ & 5 yr 1978 & $\mathbf{A}$ & - & - & SMA $1: 10$ & \\
\hline & & & Tracheobronchial & & & & & & \\
\hline & & & Histology + ve & Follow-up 1979 & & - & - & & \\
\hline 8 & $\mathrm{M} / 70$ & RPC & $\begin{array}{l}\text { Arthritis } \\
\text { Auricular }\end{array}$ & 7 yr 1979 & I & - & 一 & & \\
\hline & & & $\begin{array}{l}\text { Tracheobronchial } \\
\text { Chronic respiratory infection }\end{array}$ & & & & & & \\
\hline & & & $\begin{array}{l}\text { Ocular } \\
\text { Thyrotoxicosis }\end{array}$ & Follow-up 1978 & $\mathbf{A}$ & - & - & TGHA $1: 20$ & $\begin{array}{l}\text { MCHA } 1: 320^{2} \\
\text { PCA+ }\end{array}$ \\
\hline A & $\mathbf{M} / 49$ & Seropo & $\begin{array}{l}\text { ositive rheumatoid arthritis } \\
\text { (severe, erosive) }\end{array}$ & See Fig. 1 & & Up to $1: 320$ & & Latex positive, & SCAT positive \\
\hline B & $F / 40$ & Seropo & $\begin{array}{l}\text { ositive rheumatoid arthritis } \\
\text { (severe, erosive) }\end{array}$ & See Fig. 2 & & Up to $1: 32$ & & & - \\
\hline & & $\begin{array}{l}\text { Drug-i } \\
\text { throm }\end{array}$ & $\begin{array}{l}\text { induced haemolytic anaemia and } \\
\text { bocytopenia }\end{array}$ & - & & & & & \\
\hline C & $\mathbf{F} / 80$ & Seropo & $\begin{array}{l}\text { ositive rheumatoid arthritis } \\
\text { (severe, erosive) }\end{array}$ & & & $1: 4$ & & & \\
\hline $\mathbf{D}$ & $\mathbf{F} / 53$ & Serone & egative rheumatoid arthritis & 2 yr 1978 & & $1: 10$ & - & & MCHA 1:102 \\
\hline & & & (mild, nonerosive) & Follow-up 1979 & & $1: 10$ & - & TGHA 10 & MCHA $1: 20^{2}$ \\
\hline $\mathbf{E}$ & $\mathbf{M} / 63$ & Alcoh & olic cirrhosis & Follow up 1978 & & $1: 1$ & & SMA $1 ; 10$ & \\
\hline & & & & Follow-up 1978 & & $\begin{array}{l}1: 1 \text { weak } \\
\text { positive }\end{array}$ & & & \\
\hline
\end{tabular}

TGHA $=$ thyroglobulin antibodies (haemagglutination). $\mathrm{MCHA}=$ thyroid microsomal antibodies (haemagglutination). PCA $=$ parietal cell antibodies. IF =intrinsic factor antibodies. ICA $=$ islet cell antibodies. SMA $=$ smooth muscle antibodies. $A=$ active polychondritis. I =inactive polychondritis. 
cases the titres dropped after steroid treatment. One patient was still positive 11 years after onset of his disease.

The 3 negative RPC cases had had the disease for 3,5 , and 7 years respectively when first tested and remained negative on follow-up, though 2 were still considered to have active disease.

Well documented autoimmune endrocrinopathies were present in 2 of the RPC cases, and their sera had the appropriate organ-specific antibodies. In 2 other cases thyroid or gastric antibodies were persistently present without any clinical evidence of thyroiditis or pernicious anaemia. Thus, $40 \%$ of RPC cases had organ-specific antibodies in their sera, whereas contrary to expectation none had any significant antibodies of the non-organ-specific group.

$R A$ patients. Four patients out of the 260 screened were found to have positive IFL on cartilage (Tables 1 and 2). In 2 cases we were able to examine sera retrospectively for over 10 years. The results of these 2 cases are detailed in Figs. 1 and 2.

Patient A, a man of 49, had active RA for over 1 year before the cartilage antibodies appeared in his serum. Afterwards the antibodies remained positive and titres fluctuated between 20 and 100 for 9 years before reaching a maximum titre of $1: 320,11$ years after the onset of the arthritis. The fluctuations showed a rough correlation with disease activity and the level of the erythrocyte sedimentation rate (ESR).

Patient B, a woman aged 40, had active RA

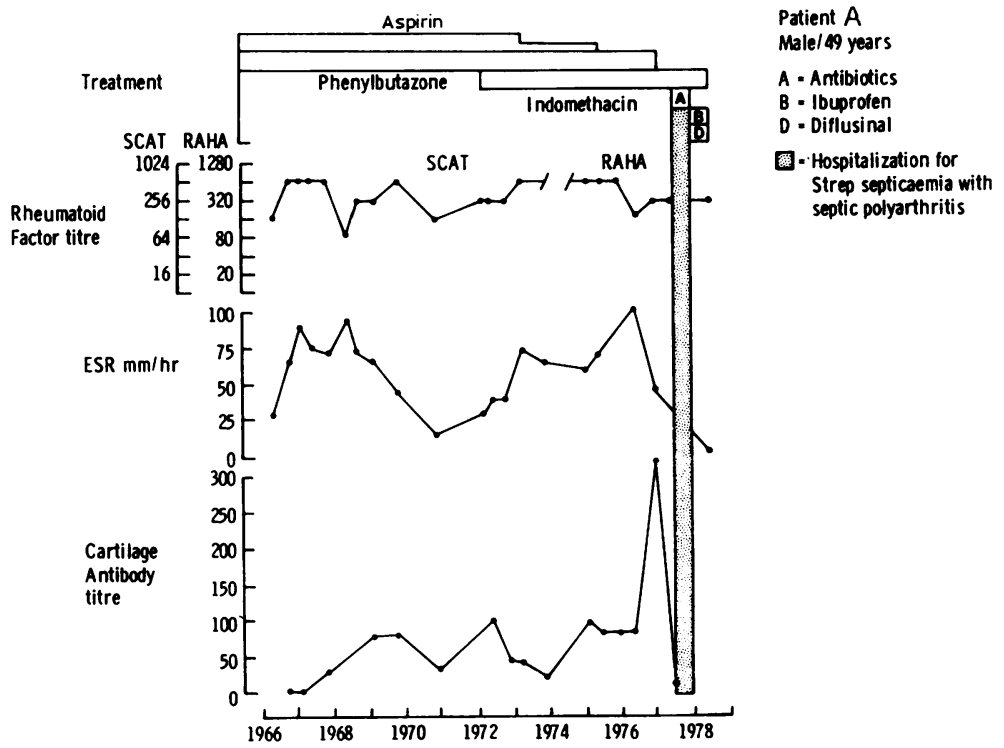

Table 2 Prevalence of fetal cartilage antibodies in relapsing polychondritis and other diseases as detected by immunofluorescence on human fetal cartilage matrix

\begin{tabular}{|c|c|c|}
\hline Disease groups studied & $\begin{array}{l}\text { Number of } \\
\text { patients }\end{array}$ & $\begin{array}{l}\text { Number of } \\
\text { positives }\end{array}$ \\
\hline $\begin{array}{l}\text { 1. Relapsing polychondritis } \\
\text { 2. Rheumatoid arthritis (RA) } \\
\text { 3. Ankylosing spondylitis (AS) } \\
\text { 4. Connective tissue diseases } \\
\text { (mixed, excluding RA and AS) } \\
\text { 5. Liver disease } \\
\text { 6. Organ-specific autoimmune } \\
\text { diseases* } \\
\text { 7. Other mixed hospital patients } \\
\text { Total }\end{array}$ & $\begin{array}{r}96 \\
106 \\
\\
480 \\
274 \\
1285\end{array}$ & $\begin{array}{ll}6 & (66 \%) \\
4 & (1 \cdot 5 \%) \\
0 & \\
& \\
0 & \\
1 & (1 \%) \\
& \\
0 & \\
0 & \\
11 & \end{array}$ \\
\hline
\end{tabular}

*Organ-specific autoimmune gastritis, diabetes mellitus, Addison's disease, and polyendocrine disorders.

followed up for 5 years before the cartilage antibodies made their appearance. There was a gradual rise of titres from 1:1 to 1:30 which appeared to coincide with rises in rheumatoid factor and ESR. The maximum cartilage IFL titre occurred around the time of a hospital admission associated with a flareup of arthritis and complications arising from her treatment.

One other severe seropositive RA patient showed cartilage antibodies to a titre of $1: 4$, but no furtherō samples were available for testing. Another sero-? negative RA patient has been found to have cartilage antibody at a titre of $1: 10$ for at least 2 years, and she also has persistent thyroid antibodies.

Other patient groups. The only other case having

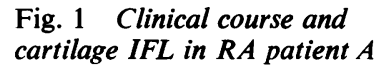




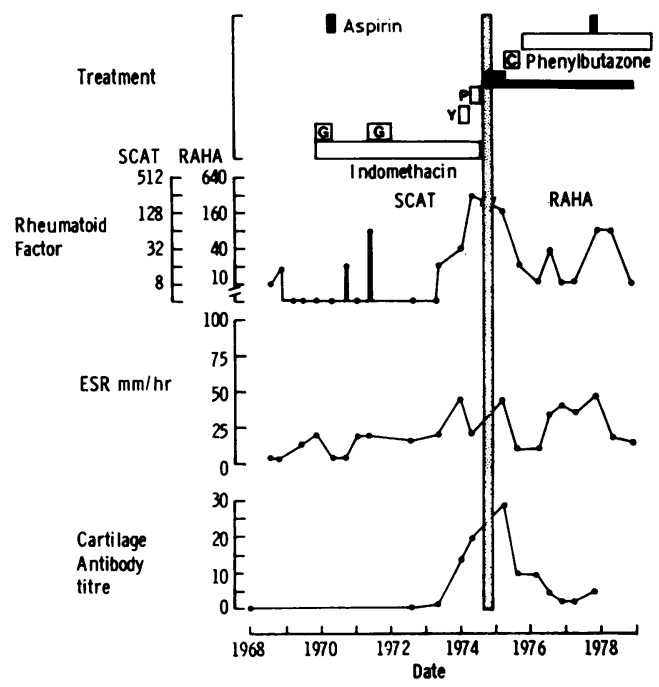

a weakly positive cartilage IFL was a 63-year-old man who had chronic alcoholic liver disease and no evidence of arthritis or polychondritis.

Cartilage antibodies were looked for in a further 105 sera from patients with autoimmune or alcoholic liver disorders but all gave negative results. Sixty cases of AS gave negative results. We also tested 96 patients with other connective tissue disorders including SLE, mixed connective tissue disease with precipitins to extractable nuclear antigen, and other less well defined syndromes. They were also entirely negative. Further control groups examined were 480 sera from patients with autoimmune endocrine diseases including some complex polyendrocrine cases and 274 mixed hospital patients with nonautoimmune disorders (Table 2).

\section{ANTIBODIES TO HUMAN COLLAGEN \\ TYPE II DETECTED BY ELISA}

Normal sera from laboratory staff were compared with RPC cases and RA patients, including those positive and negative by cartilage IFL.

Ten serum specimens from 8 patients with RPC were tested by the ELISA technique and the results together with other patient groups are shown in Fig. 3. For statistical analysis the absorbance values were converted to $\log$ values to produce a linear scale. There was a significant elevation in the mean level of antibody activity to collagen type II in the RPC sera $(t=3 \cdot 19, \mathrm{DF}=29, \mathrm{P}<0 \cdot 005)$ and IFL negative sera from RA patients $(t=5 \cdot 34, \mathrm{DF}=41, \mathrm{P}<$ $0 \cdot 001$ ) when compared with the control sera. There was no difference between RPC sera and IFL negative RA sera. Thus, although the RPC sera had evidence of activity against collagen type II, it cannot be certain to be the same antibodies as those
Patient B

Female/ 40 years

$C=$ Chloroquine

$P=D$-penicillamine

$Y=$ Yttrium

G = Sodium aurothiomalate

D. Hospitalization for rash,

thrombocytopenia, haemolysis

and jaundice possibly induced

by $D$-penicillamine

Fig. 2 Clinical course and cartilage IFL in $R A$ patient $B$

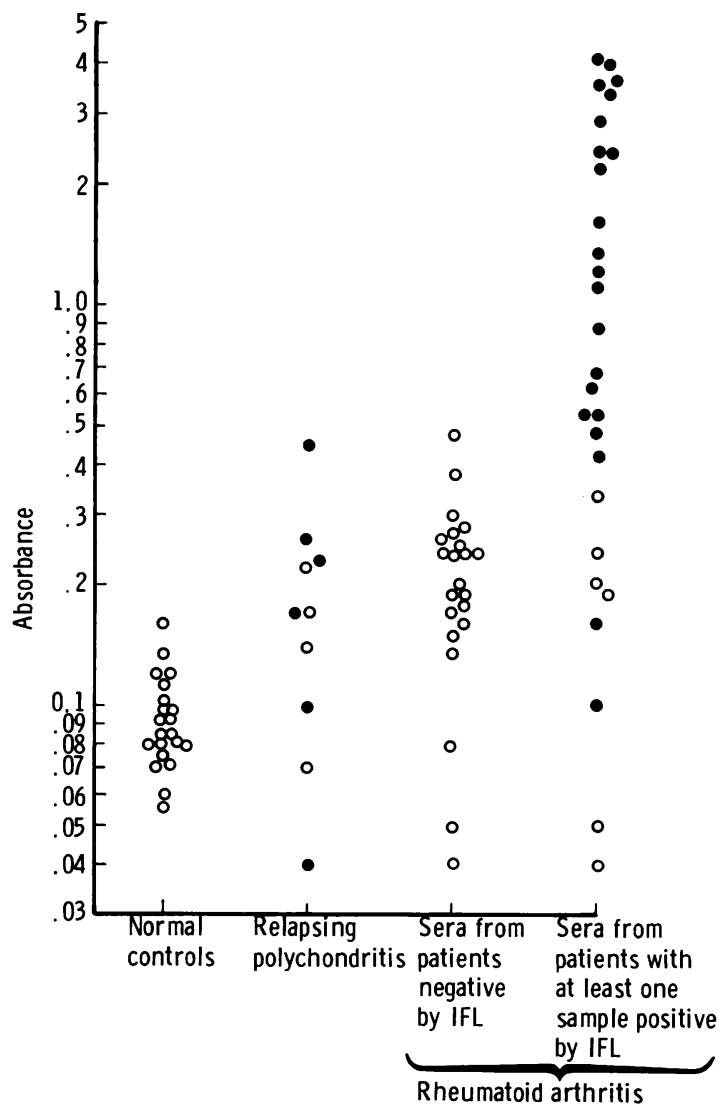

Fig. 3 IgG antibodies to human collagen type II measured by the enzyme-linked immunosorbent assay. $\bigcirc=$ Cartilage immunofluorescence negative. - Cartilage immunofluorescence positive. 
directed against fetal cartilage. Six RPC sera gave higher results for collagen type II binding than the highest normal control. Of these, 4 were positive for IFL and 2 negative. The 3 highest by ELISA had IFL titres of $1: 80$ and the fourth reacted on cartilage only at $1: 1$. Of the 4 patients with RPC sera who had ELISA values in the normal range 2 also reacted by IFL on cartilage although at 1:1 only. Sera from the 4 cartilage-positive RA patients were grouped separately, including some which had not reacted with cartilage (Figs. 1 and 2). As a group, sera from these 4 patients gave the highest readings against collagen type II detected by the ELISA technique, and the values correspond to titres several hundred-fold higher than those found in normal subjects. The antibody activity in these sera appeared to be specific to collagen type II, as there was no evidence of increased antibody activity by ELISA to native human collagen type I, III, IV, or V (G. Rook, unpublished observations). Again, however, there were discrepancies with some sera positive for cartilage IFL (at dilutions of 1:10 and 1:80 respectively) falling into the normal range on testing for collagen type II antibody. It was concluded that cartilage IFL and the collagen type II ELISA test were measuring related but distinct antibody specificities.

\section{Discussion}

The results indicate that diffuse IFL of fetal human cartilage matrix is highly specific to RPC and closely correlated with clinical evidence of acute disease. Higher titres were found in the active phase of disease, and there is a suggestion that the levels tend to fall with steroid therapy or clinical remission. Similar observations were reported by Foidart et al. ${ }^{5}$ Most RPC patients who were negative by IFL had had the disease for several years and might have shown antibodies had earlier serum samples been available. Although most cases present with visible and pathognomonic lesions in nasal and auricular cartilage, the diagnosis in other cases may be difficult. In case 2 the correct diagnosis of tracheobronchial RPC was made only after cartilage antibodies had been demonstrated. Previous IFL studies have shown mixed results. The initial observation of Dolan et $a .^{3}{ }^{3}$ reported a perilacunar and chondrocyte IFL pattern, but it was Hughes et al..$^{1}$ who showed that the positive reaction consisted of a diffuse fluorescence throughout the cartilage matrix. They observed, as we have, that some normal sera can produce the nonspecific perilacunar fluorescence. This perilacunar reaction may have some significance and needs further study. Other investigators have been unable to detect cartilage antibodies in RPC by IFL, immunodiffusion, or haemagglutination but reported cell-mediated immune responses using cartilage antigens. ${ }^{78}$ It is noteworthy that nearly half the RPC patients had evidence of other organspecific antibodies. Two cases had associated thyrotoxicosis, and one of these also had perncious anaemia and autoimmune diabetes with persistence of islet-cell antibodies. This case has been reported in detail. ${ }^{19}$ It was somewhat surprising to note the rare occurrence of nuclear and other non-organspecific antibodies in view of the frequency of arthritis and the overlap with defined collagen disorders in these patients. As we managed to study only 9 cases in as many years, this may not be a definite feature.

RA patients showing no overt evidence of RPC had cartilage IFL in $1.5 \%$ of cases, mostly in severe erosive arthritis with complications. In the 2 cartilage IFL-positive RA patients followed up from the onset of their arthritis the antibodies appeared some years after the joint disease, making it unlikely that the antibodies were involved in the initiation of the arthritis. A more likely explanation is that in a small proportion of RA cases these antibodies are produced as a consequence of joint cartilage destruction.

The absence of fetal cartilage antibodies in other diseases suggests that this pattern is highly specific? for RPC, though the 3 negative results suggest that it may be associated predominantly with early or very active disease. Cartilage IFL antibodies have been reported in the serum of about $3 \%$ of RA patients when rat tracheal or costal cartilage was the substrate used. ${ }^{20}$ These investigators noted that pretreatment with hyaluronidase enhanced the fluorescence, as we did when using adult human or guineapig or rat cartilage. Two groups of investigators have recently shown that sera with IFL cartilage antibodies in RPC patients ${ }^{5}$ and in RA patients ${ }^{20}$ also have increased activity against collagen type II. Both of these groups measured the anticollagen type II activity by a haemagglutination technique. Haemagglutination may produce anomalous reactions when measuring for anticollagen antibodies. ${ }^{15}$ This may be due to the presence of fibronectin or cold-insoluble globulin, which has specific binding activity for collagen and also binds to cell membranes. ${ }^{21}$

In our experiments the cartilage IFL could not be absorbed out with beads coated with native type II collagen or with porcine proteoglycan. Foidart et al. $^{5}$ were able to absorb out the cartilage IFL activity using collagen type II fibrils, and the IFL activity was found to return after digestion of the fibrils with collagenase. A further difference was the use of hyaluronidase-treated mouse cartilage as their 
substrate in the IFL test. These differences in technique may account for the different findings.

The investigations with the ELISA test showed that patients with RPC have higher levels of collagen type II antibody than healthy controls. Although there was some suggestion that patients with cartilage-positive IFL had higher anticollagen type II activity, some cartilage-positive sera had very low collagen binding activity. Also there was no difference in the collagen type II binding between RPC sera and the cartilage-IFL-negative RA sera. The highest anticollagen levels were found in the IFLpositive RA sera, but the increased values may be due to the presence of increased antibodies to several joint tissue components in severe destructive disease. Thus the data suggests that although cartilage IFL and collagen type II antibodies measured by ELISA are superficially parallel the tests measure distinct antibodies.

The fact that fetal cartilage reacts readily with RPC sera may mean that unmasking of fetal antigen(s) plays a role in the expression of this disease. The report of polychondritis occurring in the newborn infant of an affected mother and the subsequent recovery of the baby suggests that a serum factor or antibodies capable of crossing the placenta may be important in the production of the disease. ${ }^{22}$ The finding that cartilage antibodies are detected in the majority of cases of RPC and only rarely in other diseases suggests that these antibodies may have a key role in the pathogenesis of cartilage destruction in RPC.

We thank the many physicians who sent us sera from patients, Dr Helen Beard and Dr V. Duance for supplies of type II collagen, and Dr Helen Muir for purified porcine proteoglycan. Mr S. Bedi, chief laboratory technician, gave us invaluable help. We are also grateful to Dr Mary Corbett for allowing us to examine her prospective series of RA patients, to Professor I. M. Roitt for his continued support, and to Mrs C. Padamsey for typing the manuscript.

\section{References}

1 Hughes R A C, Berry C L, Siefert M, Lessof M H. Relapsing polychondritis. Three cases with a clinicopathological study and literature review. $Q J$ Med 1972; 41: $363-80$.

2 MacAdam K P, O'Hanlan M A, Bluestone R, Pearson C M. Relapsing polychondritis. Prospective study of 23 patients and a review of the literature. Medicine 1976; 55: 193-215.
3 Dolan D L, Lemmon G B, Teitelbaum S L. Relapsing polychondritis. Analytical literature review and studies on pathogenesis. Am J Med 1966; 41 : 285-97.

4 Shaul S R, Schumacher H R. Relapsing polychondritis. Electron microscopic study of ear cartilage. Arthritis Rheum 1975; 18: 617-25.

5 Foidart J M, Abe S, Martin G R, et al. Antibodies to type II collagen in relapsing polychondritis. $N$ Engl J Med 1978; 299: 1203-7.

6 Rogers P H, Boden G, Tourtellotte C D. Relapsing polychondritis with insulin resistance and antibodies to cartilage. Am J Med 1973; 55: 243-8.

7 Herman J H, Dennis M V. Immunopathological studies in relapsing polychondris. $J$ Clin Invest $1973 ; 52: 549-58$.

8 Rajapakse D A, Bywaters E G L. Cell mediated immunity to cartilage proteoglycan in relapsing polychondritis. Clin Exp Immunol 1974; 16: 497-502.

9 Gange R W. Relapsing polychondritis. Report of two cases with an immuno-pathological review. Clin Exp Dermatol 1976; 1: 261-7.

10 Steffen C. Consideration of pathogenesis of rheumatoid arthritis as collagen autoimmunity. $Z$ Immunitaetsforsch Immunobiol 1970; 139: 219-27.

11 Andriopoulos N A, Mestecky J, Miller E J, Bradley E L. Antibodies to native and denatured collagens in sera of patients with rheumatoid arthritis. Arthritis Rheum 1976; 19: 613-7.

12 Menzel J, Steffen C, Kolarz G, Eberl R, Frank O, Thumb N. Demonstration of antibodies to collagen and of collagen-anti-collagen immune complexes in rheumatoid arthritis synovial fluids. Ann Rheum Dis 1976; 35: 446-50.

13 Trentham D E, Dynesius R A, Rocklin R E, David J R. Cellular sensitivity to collagen in rheumatoid arthritis. N Engl J Med 1978; 229: 327-32.

14 Fleming A, Crown J M, Corbett M. Early rheumatoid disease. I. Onset. Ann Rheum Dis 1976; 35: 357-60.

15 Beard H K, Lea D J, Ryvar R. Anomalous reactions in the haemagglutination assay for anti-collagen antibodies. Studies on patients with rheumatoid arthritis or chronic low back pain. J Immunol Methods 1979; 39: 119-28.

16 Herbage D, Bouillet J, Bernego J C. Biochemical and biophysical characteristics of pepsin solubilized type II collagen from bovine articular cartilage. Biochem $J$ 1977; 161 : 303-12.

17 Voller A, Bidwell D E, Bartlett A. Enzyme-linked immunosorbent assay-a guide with abstracts of microplate applications. Guernsey: Dynatech Europe, 1979.

18 Nakane P K, Kawaoi A. Peroxidase labelled antibody. A new method of conjugation. Histochem Cytochem 1974; 22: 1084-91.

19 Clayton R N, Hoffenberg R. Relapsing polychondritis: an autoimmune disease?. Br Med J 1978; ii: 999-1000.

20 Greenbury C L, Skingle J. Anti-cartilage antibody. $J$ Clin Pathol 1979; 32: 826-31.

21 Engrall E, Rouslahti E. Binding of soluble form of fibroblast surface protein, fibronectin, to collagen. Int J Cancer 1977; 20: 1-5.

22 Arundell F W, Haserick J R. Familial chronic atrophic polychondritis. Arch Dermatol 1960; 82 : 439-441. 